\title{
PRESENTING WALT WHITMAN: "LEAVES-DROPPINGS" AS PARATEXT
}

\author{
EDWARD WHITLEY
}

IT HAS BEEN LONG RECOGNIZED that Ralph Waldo Emerson's encouraging letter to Walt Whitman after receiving a copy of the first (1855) edition of Leaves of Grass was instrumental in securing future success for the poet. Ed Folsom and Gay Wilson Allen write, "If it hadn't been for Emerson's electrifying letter greeting Whitman at 'the beginning of a great career,' the first edition of Leaves of Grass . . . would have been a total failure; few copies were sold, and Emerson and Whitman seemed about the only people who recognized much promise in it." ${ }^{1}$ But comforting as it must have been to a disheartened Whitman, Emerson's letter did more than heal a bruised ego. Whitman aggressively used the letter to promote sales of future editions of Leaves of Grass by having it quickly published (without Emerson's permission) in the New York Tribune $^{2}$ and by embossing the key words from Emerson's letter, "I Greet You at the / Beginning of A / Great Career / R W Emerson," on the spine of the second (1856) edition. Nowhere is this use of Emerson's letter for self-promotion more evident than in "Leaves-Droppings," the appendix to the second edition of Leaves of Grass, which contains Emerson's letter, Whitman's reply (which was never actually sent), ${ }^{3}$ and nine previously published reviews of the 1855 edition.

As an appendage to the text proper of Leaves of Grass, "LeavesDroppings" falls within the realm of what Gerard Genette has identified as the paratext, those elements which are related to but not directly a part of the text itself. ${ }^{4}$ Genette divides the paratext into peritext - things like titles, forewords, prefaces, epigraphs, notes, and appendices, which, while separate from the text proper, fall within the material bounds of the book-and epitext, which is "any paratextual element"-such as an interview, announcement, or letter-"not materially appended to the text within the same volume but circulating, as it were, freely, in a virtually limitless physical and social space" (344). By providing a "threshold of interpretation," the paratext "provides some commentary on the text and influences how the text is received" (7). Paratextual elements "surround and extend [the text] . . . in order to present it, in the usual sense of the verb but also in the strongest sense: to make present, to 
ensure the text's presence in the world, its 'reception' and consumption" (1). As a promotional effort focused on improving the public and critical reception of Leaves of Grass, "Leaves-Droppings" is a prime example of paratext working to "ensure the text's presence in the world."

While Whitman's tendency towards self-promotion has previously been noted, ${ }^{5}$ Genette's theory of the paratext provides a language for analyzing how Whitman manipulates the elements surrounding Leaves of Grass and turns them into "Leaves-Droppings." While looking at "Leaves-Droppings" as paratext provides a framework for considering what Whitman accomplished, there are key ways in which Whitman's use of paratext necessarily differs from Genette. While it is central to Genette's definition that paratext be authorial (he says that the paratext is "always the conveyor of a commentary that is authorial or more or less legitimated by the author"), ${ }^{6}$ Whitman's inclusion of texts written by other people reveals not only the substantial impact non-authorial writing has on how readers receive a text, but also the implications of using someone else's writing to promote one's own. While Genette's definition of paratext as only that which "the author or one of his associates accepts responsibility for" would remove Emerson's letter and the reviews of Leaves of Grass from consideration as elements which present a text to an audience, Whitman's use of them betrays the fact that they were already presenting his text to the world (Genette, 9). This engagement with non-authorial material, specifically the movement of Emerson's letter and the reviews from the unbounded, diffuse realm of the epitext of newspapers and periodicals to the controlled realm of the peritext in a printed book, reveals the lengths Whitman was willing to go to in order to fulfill his vision for American poetry and of himself as America's poet.

Section one of this essay focuses on how Whitman uses Emerson's letter and his open-letter reply to lay the groundwork for a narrative which would influence the reading of the reviews in "Leaves-Droppings." This narrative is designed to use Emerson's letter as an endorsement of Whitman's poetic project and to distance Whitman from many of Emerson's poetic ideals. Section two shows how the narrative Whitman creates of himself and his poetry plays out in his selection and ordering of both positive and negative reviews of the 1855 Leaves of Grass. Section three considers the possible implications of the movement of material from the epitext of the newspaper press to the peritext of a printed book in a nineteenth-century print culture which associated the press with democracy. This final section suggests a consideration of what Whitman's movement of Emerson's letter and the reviews through the realms of paratext reveals about the intersection of print and democracy, a key location to understanding the printer-turned-poet whose project for American literature was deeply invested with both. 
Caught as he was in "an insufficient system of marketing and promotion under which ... American authors often languished," ${ }^{, 7}$ Whitman had to find a way to make the second edition of Leaves of Grass convince the world that he was indeed the American bard he claimed to be. With popular and critical reception of the 1855 Leaves of Grass at a low point, Whitman shaped the paratext of the 1856 edition in a way that would not only reduce the effect of previous negative criticism but would encourage future critics and lay readers alike towards positive readings. Genette writes, "The author never approaches a new public without having more or less strongly felt the reaction of the first one-in particular the reaction of the kind of reader who is hardly likely to take another look and correct himself on the occasion of a new edition: the critic" (240). Knowing that negative reviews were affecting how his book was received and that Emerson's letter could be used to affect reception, Whitman devised "Leaves-Droppings" as a way to take the epitextual material which was out of his control and bring it into the peritext that he had control over. Since, as Genette says, the epitext's "lack of external limits" gives it a "potential for indefinite diffusion" (346), "LeavesDroppings" is about controlling diffusion. In controlling this diffusion, Whitman included nine negative and positive reviews from both England and the United States in a sub-section of "Leaves-Droppings" titled "Opinions, 1855-6." While it could be argued that by including both negative and positive reviews Whitman was working on the principle that any publicity is good publicity, ${ }^{8}$ these reviews, along with Emerson's letter and Whitman's reply in a sub-section titled "Correspondence," form a coherent narrative describing what Whitman considered to be American literature and his place within it. Emerson's letter and Whitman's reply create a context for the reviews as a way to contain their potentially negative diffusion.

As Whitman moves this material from the diffuse epitext to the bounds of the peritext, he takes on the role of the editor, whose work, Jerome McGann argues, "is more an act of translation than of reproduction." Whenever someone selects, collects, and places a text in a new environment, McGann argues, he or she will necessarily change its meaning by translating it from the original context. Whitman's "translation" of Emerson's letter aggressively manipulates the meaning of Emerson's words without changing a single line, since moving their proximity to his text is enough to change their meaning. As private epitext, Emerson's "I greet you at the beginning of a great career," 10 addressed solely to Whitman, reads, "I encourage you as a beginning writer." When Whitman has the letter published in the New York Tribune and changes 
it to public epitext, its meaning shifts in relation to its new audience, who read it as an advertisement saying "I heartily endorse the purchase of this book." A further change in meaning occurs when Whitman includes the letter in "Leaves-Droppings." In its position as peritext, the letter takes on the characteristics of a commissioned endorsement written specifically for inclusion with the book. As Genette says, "To write and sign [an endorsement] for someone else's book signifies . . . 'See, on his behalf I'm even doing a task that's usually menial, which tells you how highly I value his work." "11 But Emerson's letter provides more than just promotion (the blurb on the spine is sufficient for that). Along with Whitman's reply, the two letters serve as a touchstone for integrating the positive and negative reviews which follow them into a narrative Whitman constructs of American literature and of himself as the American poet.

Emerson plays a crucial role as America's preeminent man of letters in this narrative. As Jerome Loving says, in 1855 "Whitman was already thinking of reprinting the letter again and more prominently, linking Emerson forever to Leaves of Grass, in the 1856 edition" (Loving, 211). The linking of Emerson to Whitman is evident in the pun on "eavesdropping" in "Leaves-Droppings" that makes readers feel that they are listening in on a private conversation between friends. ${ }^{12} \mathrm{By}$ making eavesdroppers of his readers, Whitman repositions them as the secondary audience of his text, making it seem that Emerson is not only the primary audience for his letter, but for all of Leaves of Grass as well. $\mathrm{He}$ begins his reply letter, "Here are thirty-two Poems, which I send you, dear Friend and Master." 13 Presumptuous in tone-they had met only once, so they could hardly be called "Friends," and Whitman had never directly studied with the man, so "Master" seems a stretch-the letter is designed to make readers feel as if they are being privileged to glimpse the communication between literary greats (see Kaplan, 211212). As Genette says about the nature of literary correspondence, quoting Hugo to Lamartine, "to respond to Raphael, one has to be Michelangelo" (381). But even though Whitman seems to indicate his discipleship to "Master" Emerson, elsewhere in his reply letter he seems to indirectly and directly criticize him. As Kenneth Price observes, "In his 1856 letter Whitman attempted to achieve a number of incompatible goals. He wanted to acknowledge, praise, and thank Emerson for pointing the way toward a truly American literature. But at the same time, he insisted that no one was writing great American poetry, that all writers had fallen short of the mark, Emerson included." ${ }^{14}$ Jay Grossman concurs: "The 1856 edition wants to have it both ways (at least): to marshal the full marketing potential of Emerson's endorsement even while marking its differences from Emerson and from 'traditional' poetry more generally" (83). 
Grossman argues that class distinctions affect the way the two writers define poetry, and he calls attention to the facts that Emerson never uses the words "poetry," "poet," or "poem" in his 1855 letter-rather, he congratulates Whitman on his "wit and wisdom" (LG, 729)—and that Whitman's response to this in the 1856 Leaves of Grass is to conspicuously insert the word "poem" in every title of the book. ${ }^{15}$ Loving also sees this engagement with Emerson as a debate over the meaning of poetry: "Whitman's acceptance as a great poet would happen only when the criteria for poetry changed. In the open letter to Emerson in the 1856 edition . . . Whitman tried to redefine American poetry and the American poet" (220). Central to this redefinition of poetry is Whitman's statement that the true American poet, even though "the work of [his] life is making poems," is he who will "meet people and The States face to face, to confront them with an American rude tongue" ( $L G, 730$ 731). The change in modifier in this statement from the more conventional "rude American tongue" to "American rude tongue" makes rudeness an essential quality of Americanness, and thereby takes American letters away from the Emersonian tradition and gives it to "Walt Whitman, an American, one of the rough" ( $L G, 52 \mathrm{n})$.

Similarly, as Whitman presents himself in his reply letter as the leader of "the born throngs of poets, literats, orators, you promised" $(L G, 732)$, he takes advantage of the potential for ambiguity over the referent of "you" in this statement. While the letter is ostensibly addressed to Emerson, the context of the paragraph suggests that Whitman has switched over to addressing America itself. ${ }^{16}$ As Price writes, "Whitman's generalized censures for the specific praise of Emerson ... [are] placed in key rhetorical positions, the introduction and the conclusion" (84). This ambiguity allows Whitman both to reject Emerson and address America directly, and to harness a connection with Emerson, as Whitman seems to be responding to the transcendentalist philosopher's 1843 essay, "The Poet," where he writes, "I look in vain for the poet whom I describe." Poet" as the real text Whitman is responding to in his reply letter, especially given that Emerson says in his letter that Whitman's book "meets the demand I am always making" for American poetry $(L G, 729)$. As Anthony Szczesiul says of Whitman's letter in the 1856 edition, "Whitman consciously hoped to answer ... 'The Poet', which called for a truly original national poet, one who would sing of the new country in a new voice." 18 For example, in "The Poet" Emerson writes, "We have had no genius in America, with tyrannous eye, which knew the value of our incomparable materials. ... [America is] yet unsung. Yet America is a poem in our eyes; its ample geography dazzles the imagination, and it will not wait long for meters." 19 Whitman, seeming to echo this sentiment in his reply letter, writes, "America is a divine true sketch," and 
then hints at the poet who should "stand to nothing less than the freshest and freest expression" in his attempt to transcribe the American sketch into printed words $(L G, 736)$.

While Whitman invokes "The Poet," he seems to take what he can from it and then revise both it and Emerson to present the narrative of the poet with the "American rude tongue" that will dominate the rest of "Leaves-Droppings." Even though Whitman very well contradicts himself in presenting himself as the Emersonian poet and in showing Emerson's failings - he reserves the right to "both blaspheme and worship" 20 - he hopes the overall message of "Leaves-Droppings" will clearly present him as America's poet both as heir to the Emerson legacy and as a radical departure from Emerson. He evokes Emerson's sentiments from "The Poet" that the true poet of America will realize that "Milton is too literary, and Homer too literal and historical" to serve as models for American poetry ("The Poet," 368) and then echoes this sentiment in his letter-"Old forms, old poems, majestic and proper in their own lands here in this land are exiles" ( $L G, 734)$. In so doing, Whitman is not only able to make any mention of the necessarily rude American character of Leaves of Grass, be it good or bad, fit within the Emersonian framework of this narrative, but also to include Emerson in the category of "old forms" and "old poems" his vision of American poetry rejects.

In "The Poet" Emerson writes, "So the poet's habit of living should be set on a key so low that the common influences should delight him. ... If thou fill thy brain with Boston and New York, with fashion and covetousness, and wilt stimulate thy jaded senses with wine and French coffee, thou shalt find no radiance of wisdom in the lonely waste of the pine woods" (366). While Whitman agrees in his reply letter that "America is to be kept coarse and broad" ( $L G, 733)$, he criticizes the school of American literature which is "dressed up, a fine gentleman, distasteful to our instincts, foreign to our soil" $(L G, 734)$, such that his implicit agreement with Emerson is also an explicit critique of Emerson as the "fine gentleman" of American poetry. He writes, "every [American writer] has demeaned himself to some etiquette or some impotence. There is no manhood or life-power in poems; there are shoats and geldings more like," and he makes the bold pronouncement, "There is no great author," including "Master" Emerson himself $(L G, 734)$. Lest this sweeping indictment be lost on readers, Whitman goes on to say that no writer in America understands nature, a direct assault on Emerson's nature-worshiping transcendentalism. Whitman writes of what could easily be seen in this framework as transcendentalism itself: "Its costumes and jewelry prove how little it knows Nature. Its flesh is soft; it shows less and less of the indefinable hard something that is Nature. Where is any thing but the shaved Nature of synods and schools? Where is a savage and luxuriant man?" ( $L G, 734)$. Emerson, it seems, is missing the essential rough and rude character of Americanness that 
Whitman finds so essential to the true American poet. "Such character," Whitman writes towards the end of his reply letter, "is the brain and spine to all, including literature, including poems" ( $L G, 738)$. Suggesting that Emerson is both spineless and brainless, Whitman thus sets the tone of the rude American character central to his poetry.

\section{II}

The reviewers Whitman places in the "Opinions, 1855-6" subsection of "Leaves-Droppings" alternately praise and pan him for the rough and rude American character of Leaves of Grass. The first three reviews are positive in tone and link Whitman with Emerson. The next two reviews are mixed, and the last four are decidedly negative, specifically denouncing the rude American character of both Whitman and his poetry. It is the rudeness and Americanness of his writing, highlighted in both positive and negative reviews, which Whitman hopes to call attention to as virtues in his poetry, whether reviewers extol or denounce him for them. In the unbound world of the epitext in which ideas are diffused ad infinitum, these reviews have the potential of presenting a different text than Whitman would like readers to receive. But within the context of Emerson's letter and Whitman's reply, Whitman controls the narrative of the virtues of the American rude tongue that emerges in "Leaves-Droppings."

The first review in "Leaves-Droppings" is a short, positive appraisal from the London Weekly Dispatch, the most conspicuous phrases of which are: "What Emerson has pronounced to be good must not be lightly treated" and "We have before us one of the most extraordinary specimens of Yankee intelligence and American eccentricity in authorship it is possible to conceive." 21 The narrative of "Leaves-Droppings," depending as it does on the American character of Whitman's poetry and its connection with Emerson, takes full advantage of this international review $^{22}$ for perceiving what he hopes all readers will perceive, namely, "Yankee intelligence and American eccentricity." That it appears first among the reviews is not coincidental given the overarching narrative of "Leaves-Droppings." The anonymous reviewer then goes quickly from praising Whitman's Americanness to praising his rudeness: "the unhesitating frankness of a man who 'believes in the flesh and the appetites,' and who dares to call simplest things by their plainest names, convey[s] also a large sense of the beautiful" (Price, 41). The second review, anonymously written by Whitman and originally published in the Brooklyn Daily Times, highlights Whitman's American rudeness, saying that the poet is "Of pure American breed, large and lusty. . . . A rude child of the people!-No imitation-No foreigner-but a growth and idiom of America. . . . not for a model but an illustration, for the present and future of American letters and American young men." ${ }^{23}$ 
Price says that Whitman only wrote these self-reviews when there was a lag in the periodical and newspaper press of reviews of the 1855 edition, and that "He battled to get his book a hearing and to frame key interpretive questions." 24 "Leaves-Droppings" continues this agenda to "frame key interpretive questions" within a scope that Whitman approved of. While the idea of a self-review was by no means original with Whitman (Genette, 348), it bears noting that Whitman includes a second, much less favorable self-review later on in "Leaves-Droppings." Originally published in the American Phrenological fournal, it is a mixed review- "He is to prove either the most lamentable of failures or the most glorious of triumphs, in the known history of literature"-in which he compares himself to Tennyson and shows the differences between British and American poetry. ${ }^{25}$ While British poetry, he writes, "has grown out of the facts of the English race," such poetry does not match the American experience: "what very properly fits a subject of the British crown may fit very ill an American freeman. . . . [I]f the Americans want a race of bards worthy of 1855, and of the stern reality of this republic, they must cast around for men essentially different from the old poets" (Price, 23). While the Whitman of this review is less certain than the Whitman of the previous review that the author of Leaves of Grass is indeed a bard "worthy of 1855," what remains constant is the parallel narrative of rough and rude American poetry which runs throughout "Leaves-Droppings" from Emerson's letter to the final review.

The positive third review was originally published in the Christian Spiritualist and is less concerned with the poetry itself than with the poet's relation to Emersonian and American ideals. After saying that "Ralph Waldo Emerson is the highest-type" of spiritual leader in the world, it says that within Leaves of Grass "[a] portion of that thought which broods over the American nation, is here seized and bodied forth by a son of the people, rudely, wildly." 26 The image of a "rude" and "wild" Whitman, "a son of the [American] people," continues into the fourth review, anonymously written by Harvard art history professor Charles Eliot Norton: "words usually banished from polite society are here employed without reserve. ... [T] he introduction of terms never before heard or seen, and of slang expressions, often renders an otherwise striking passage altogether laughable." 27 Appearing originally in Putnam's Monthly, Norton's review focuses on Whitman's rough Americanness, saying that the poet's self-identification in "Song of Myself" ("Walt Whitman, an American, one of the roughs") is a needless redundancy: "That he was an American, we knew before, for, aside from America, there is no quarter of the universe where such a production could have had a genesis. That he was one of the roughs was also tolerably plain" (Price, 18). It should be just as plain to readers of "Leaves-Droppings" that Whitman's American roughness is the unfolding narrative here. Following almost word for word from Norton, the 
sixth review is an anti-American diatribe from the London Critic, which, after quoting the same line from "Song of Myself," states, "The words 'an American' are a surplusage, 'one of the roughs' too painfully apparent." ${ }^{28}$ Even before it becomes clear to readers how closely related this and the previous review are in linking together the narrative of Whitman's rude American roughness, the review begins, "We had ceased, we imagined, to be surprised at anything that America could produce," and then continues beyond the bounds of uncouth American literary production to the farce of New World travel narratives: "We had become stoically indifferent to [America's] Wooly Horses, her Mermaids, her Sea Serpents, ... . but the last monstrous importation from Brooklyn, New York, has scattered our indifference to the winds" (Price, 43). The remainder of the review is content to hurl "American" as an epithet at both Whitman and his poetry until, in a fascinating move, the reviewer compares Whitman to Shakespeare's Caliban: "Walt Whitman reminds us of Caliban flinging down his logs, and setting himself to write a poem. In fact Caliban, and not Walt Whitman, might have written this: . . . 'I sound my barbaric yawp over the roofs of the world"' (Price, 44). The comparison of Whitman to Caliban, the essence of the New World, becomes a compliment, not a criticism, in the narrative of "LeavesDroppings." While the review ends with what it clearly considers a scathing indictment of Whitman (it says it is content with quoting Whitman himself to describe the reviewer's overall opinion of him: "I talk wildly, I am mad"), the poet makes the review fit into a narrative in which wild American talk is a poetic virtue (Price, 46).

A key Emersonian virtue from "The Poet" which this sixth review invokes only to rebuke is how "bare lists of words" form part of rough American speech. Emerson writes that in the poet's imagination, "Bare lists of words are found suggestive to an imaginative and excited mind" ("The Poet," 363). This sixth review says that Whitman's poetry, rather than succinctly describing an idea, "instances a thousand paltry, frivolous, and obscene circumstances" (Price, 45). To illustrate this, the reviewer compares a single line of Shakespeare with twenty of Whitman, and then asks forgiveness for doing so: "mighty shade of the mightiest bard, forgive us the comparison!" (45). That the words are bare lists, and that these words are incomparably different from those of British bards, however, turns out to be more compliment than critique in the framework of "Leaves-Droppings." The seventh review, from the London Examiner, is harsh, calling Whitman a "wild philosopher and poet . . . perpetually haunted by the delusion that he has a catalogue to make." ${ }^{29}$ Whitman's trademark catalogues of people and things are the main focus of critique in this review. While the reviewer is aware of Emerson's praise of Leaves (he quotes several lines from the letter in the review), he finds a way to turn Emerson's compliment that Leaves of Grass is "the most extraordinary piece of wit and wisdom that America 
has yet contributed" into a criticism, especially given the dual role which Whitman makes Emerson play in this drama. ${ }^{30}$ As a rebuttal to Emerson's praise, the reviewer from the Examiner tries to show that America has always produced the kind of "wit and wisdom" featured in the Whitmanian catalogue. To prove that there is nothing unique about Whitman, the reviewer imagines that an auctioneer born in the backwoods of America who stumbles across Emerson and Carlyle and then sets out to become an "American Shakespeare" would end up writing exactly like Whitman (42). To make his point, the reviewer ends his review by quoting what he claims to be "A Catalogue of the Household Furniture with the select condition of scarce, curious, and valuable books of Dr. Goldsmith, deceased, which by order of the adm ${ }^{\mathrm{r}}$, will be sold by auction, \&c., \&c." After comparing the "bare lists of words" of an auctioneer with that of Whitman, the reviewer asks "whether the poetry of that excellent . . . auctioneer . . . does not transcend in wisdom and in wit, 'the most extraordinary piece of wit and wisdom that' (according to Mr. Emerson) 'America has yet contributed"' (43).

The eighth review, published in the London Leader, judges Leaves of Grass less harshly for its American character but nevertheless says that "The poem is written in wild, irregular, unrhymed, almost unmetrical 'lengths'. . . . The external form, therefore, is startling and by no means seductive to English ears ... [which also] deplore the unnecessary openness with which Walt reveals to us matters which ought rather to remain in sacred silence." ${ }^{31}$ The review recognizes the American fount from which Whitman's roughness arises and calls the poet a "rough, devilmay-care Yankee" with "an all-pervading Yankee-doodle about him" (50). Published in the Boston Intelligencer, the ninth review is a short, two-paragraph invective which condemns Leaves of Grass in no uncertain terms: "This book should find no place where humanity urges any claim to respect, and the author should be kicked from all decent society as below the level of a brute. There is neither wit nor method in his disjointed babbling, and it seems to us he must be some escaped lunatic, raving in pitiable delirium." 32 In an unbound, diffuse epitext, these words could spell disaster for a poet wishing to present his text as the fulfillment of his vision of American poetry to the world. Within the peritext, however, no kinder words could be spoken for this American poet.

\section{III}

Highlighting the connection Whitman makes in his open-letter reply between his goal for a new American poetry and the print media in which this goal was to be achieved, Loving says that "Whitman's brand of poetry would be in high demand in the future he foresaw, when it would be based on the emerging American imagination as it was brought 
forth by the emerging print technology and book distribution" (220221). The "emerging print technology and book distribution" of nineteenth-century America that Loving attributes to the full realization of Whitman's poetic vision was part of the larger phenomenon of modern print culture. James L. Machor says that the mass market created by "major advances in printing and book production. . . . affect[ed] the ways American writers engaged their audiences." ${ }^{33}$ One significant factor affecting this author-audience relationship was whether a text was published in a periodical or a book. In a study on the role of the periodical in nineteenth-century American literature, Susan Belasco Smith and Kenneth Price argue that " $[\mathrm{t}]$ he periodical-far more than the bookwas a social text, involving complex relationships among writers, readers, editors, publishers, printers and distributors," and they call attention to media scholarship that draws a "distinction between the 'closed' form of books, which asserts 'the dominant structures of meaning by closing off alternative options and offering the reader or viewer only one way of making sense of the text,' and the 'open' form of periodicals, 'which refuses the closed ending and allows for the possibility of alternative meaning.' [Such scholarship] suggests that books, with firm bindings and solid feel, are very different from the flexible covers and consumable nature of newspapers or magazines" (3, 9-10). They make a case for "the democratic nature of the periodical and the way in which readers are invited to be unusually active participants in the reading" and say that "periodicals may be seen as democratic and nonhierarchical" in ways that books are not (9-10). While Smith and Price admit that "this perception is open to question and challenge" because it would overstate the case to argue that periodicals are inherently more democratic than books (10), it is worth considering that Whitman's movement of Emerson's letter and the reviews from the diffuse, even democratic epitext of the periodicals to the closed peritext of the book presents us with an image that seems odd for the poet we associate so closely with both print and democracy, and who, unlike most "[n]ineteenthcentury authors [who] generally had little or no control over the final editing and printing of their work," was intimately involved in the printing, publishing, and distribution of his poetry (9).

The connection between print and democracy is a historical commonplace, with book historians like David Hall arguing that in the nineteenth century "the history of printing and the history of politics and society achieved tenuous connection through themes like the "rise of the common man', the rise of democracy." 34 Though tenuous, the experience for many nineteenth-century American writers - including Emerson and Whitman-was that print was essential to achieving their democratic goals. Emerson's enthusiasm for the periodical press is evident in an 1854 essay in which he calls newspaper production a "silent revolution" which has "take[n] in all classes. Look into the morning trains 
which, from every suburb, carry the business men into the city to their shops, counting-rooms, work-yards and warehouses. With them enters the car-the newsboy, the humble priest of politics, finance, philosophy, and religion. He unfolds his magical sheets-twopence a head his bread of knowledge costs - and instantly the entire rectangular assembly, fresh from their breakfast, are bending as one man to their second breakfast." ${ }^{35}$ As Emerson observes newspaper readers "bending as one man," we catch a glimpse of the democratic unification of people "in all classes" through print.

Whitman also echoes the centrality of print to American democracy in his "Leaves-Droppings" reply letter when he addresses America, saying "You are young, have the perfectest of dialects, a free press, a free government" ( $L G, 732)$. His praise for America is that "Of the twenty-four modern mammoth two-double, three-double, and fourdouble cylinder presses now in the world, printing by steam, twentyone of them are in These States" $(L G, 733)$. He continues to stress the necessary link between the technology of the press and the destiny of America, saying with visionary fervor, "I see plying shuttles, the active ephemeral myriads of books also, faithfully weaving the garments of a generation of men, and a generation of women" ( $L G, 733)$. Of the importance of newspapers to democracy he writes, "the three thousand different newspapers . . . the story papers, various, full of strong-flavored romances, widely circulated-the one-cent and two-cent journals - the political ones, no matter what side . . . all are prophetic; all waft rapidly on" ( $L G, 733)$. When Whitman mentions "the political [newspapers], no matter what side," he all but claims that the medium is more important than the message, satisfied just that there be printed material in democratic America. He also says that these printed materials "are prophetic" and "waft rapidly on," evoking with religious zeal the indispensable nature of accessible, printed material to a strong American democracy. In concluding this meditation on the place of the press in democratic America, Whitman connects print and democracy back to his own project as a writer, specifically as the poet of rough and rude American letters when he writes, "What a progress popular reading and writing has made in fifty years! What a progress fifty years hence! The time is at hand when inherent literature will be a main part of These States. . . . Of course all literature, in all nations and years, will share marked attributes in common, as we all, of all ages, share the common human attributes. America is to be kept coarse and broad" ( $L G, 733)$. Whitman effortlessly makes this transition from American print and democracy to his ideal for American literature, connecting his vision of the "coarse and broad" American literature with the technology of print. 
Genette's theory of the paratext is useful here in understanding the implications of Whitman's use of the texts in "Leaves-Droppings" with his faith in the democratic nature of the press. Whitman's transformation of epitext (Emerson's letter, the reviews) into peritext ("LeavesDroppings") is unique as an example of what Genette calls "later paratext." While paratext has a spatial relationship to the text proper (epitext is distant, peritext is near), it also has a temporal relationship, which Genette labels prior (coming before the publication), original (simultaneous with publication), later (coming in second and subsequent editions), and delayed (appearing in [usually] posthumous editions) (Genette, 5-6). While prior and original paratext indicate how a text is introduced to readers, later paratext like "Leaves-Droppings" shows how authors respond to the reception of their books. Genette writes, "later compensation ... takes the form of a response to the first reactions of the first public and the critics. Without any doubt that is the main function of the later preface or postface" (240). Significant to this situation is that "Leaves-Droppings," while appearing as it does at the end of the text, is not a proper postface. While Whitman's open letter to Emerson could be considered the preface to the 1856 edition, ${ }^{36}$ the fact that it is presented as a letter and not a postface influences its paratextual reception, since, as Genette says, "a large part of the message lies in the nature of the medium" (403). Also, since Whitman's letter does not stand alone, all of "Leaves-Droppings" should be considered as performing the function of a postface. "Leaves-Droppings," not written exclusively by the author as a postface would be, is not even allographic, a term which Genette uses to describe paratextual material which is written by one of the author's allies to communicate what the author would say were it not improper for him to say it. ${ }^{37}$ Since it would be unseemly for authors to overtly tell readers how to read their text, Genette argues, authors nevertheless finds some way to get their point across. He writes, "if the job does not end up getting done, it is better to take charge- not to dot the $i$ 's oneself, certainly, but to have others dot them, duly chaptered: I don't want to say anything, but nonetheless it is necessary that "that be known"' (351). While Genette says that non-authorial paratext must be "duly chaptered," Emerson and the reviewers are drafted into the role of $i$-dotter without their allographic consent.

This lack of consent is crucial given Grossman's claim that Whitman's 1856 open-letter reply to Emerson creates a "territory of contestation . . . at a site that we might call participatory democracy" (92). That this "territory of contestation" occurs in the peritext of a book rather than the epitext of a newspaper or periodical is not without relevance. Whitman's willingness to control the relative boundlessness of the periodical by transferring it to the bounds of the book leads to another observation by Grossman about Whitman's complicated relationship with the individual speaking voice and the collective voice of 
democracy: "And as for Whitman, we have still to uncover the full complexities, and the historical referents, for the poet as Common Man whose initial project nevertheless reads like a variation of Pubilus's plans for what he tellingly calls Union: 'Through me many voices"' (93). Extending Grossman's argument that reading Whitman is the experience of "[r]eading as participatory democracy" (86) to include the complexities inherent in printing as participatory democracy, we see in "Leaves-Droppings" the core issues of democracy that Whitman struggled with throughout his poetry. ${ }^{38}$ In Leaves of Grass, Whitman the poet struggled to create the speaking voice of the individual who could express the multiple voices of a democracy. In "Leaves-Droppings," Whitman the printer, publisher, and promoter confronted the problem of subsuming the diffuse, democratic epitext of the press into the bounded peritext of a book.

Whitman would come to regret "Leaves-Droppings," perhaps for the very conflict with the democratic spirit of the press the project engendered. He wrote in a letter to Sarah Tyndale about plans for the third edition of Leaves of Grass: "In the forthcoming Vol[ume] I shall have, as I said, a hundred poems, and no other matter but poems-(no letters to or from Emerson-no notices, or any thing of that sort.) I know well enough that that must be the true Leaves of Grass." 39 While this letter dismisses the "other matter" of paratext from forming part of "the true Leaves of Grass," "Leaves-Droppings" shows Whitman's awareness that "other matter" is always presenting a text, whether in the "true" authorial form of the peritext or the unbounded realm of non-authorial epitext. And while Whitman expressed his regret to Tyndale for the "other matter" he appended to his text, he didn't completely recant his penchant for self-promotion. To publicize the third (1860) edition of Leaves of Grass that he mentions in this letter, Whitman put together Leaves of Grass Imprints, a 64-page promotional pamphlet of positive, negative, and self-reviews (see Kaplan, 209). What distinguishes Imprints from "Leaves-Droppings," however, is that Imprints, as a more traditional advertising supplement in the open realm of the epitext, was its own separate entity, removed from the bounds of the text proper of Leaves of Grass. Whitman's attachment of epitextual material in the peritextual "Leaves-Droppings" reveals the lengths he was willing to go to at this early stage to establish himself as America's poet. It also illustrates his conflicted location at the intersection between print and democracy, two issues central to understanding the poet who engaged so actively with both.

University of Maryland, College Park 


\section{NOTES}

1 Ed Folsom and Gay Wilson Allen, "Introduction: 'Salut au Monde!" Walt Whitman and the World, ed. Gay Wilson Allen and Ed Folsom (Iowa City: University of Iowa Press, 1995), 1.

2 Justin Kaplan, Walt Whitman: A Life (New York: Bantam, 1982), 205.

3 Jerome Loving, Walt Whitman: The Song of Himself (Berkeley: University of California Press, 1999), 211-212.

4 Gerard Genette, Paratexts: Thresholds of Interpretation, trans. Jane E. Lewin (Cambridge: Cambridge University Press, 1997).

5 See Emory Holloway, "Whitman as His Own Press-Agent," American Mercury 18 (1929), 482-488.

6 Genette, 2. Genette discounts non-authorial material from the realm of paratext because he is approaching the paratext as a scholar, not a reader, looking for authorial material which will help to make informed scholarly readings. While scholars like Genette accept only those documents they deem to be authorial as having any bearing on their readings of a text, "Leaves-Droppings" shows that not all readers sift through paratexts with an eye to discerning what is and what is not authorial.

7 Jay Grossman, "Rereading Emerson/Whitman," Reciprocal Influences: Literary Production, Distribution, and Consumption in America, ed. Steven Fink and Susan S. Williams (Columbus: Ohio State University Press, 1999), 76.

8 In Walt Whitman and the American Reader (New York: Cambridge University Press, 1990), Ezra Greenspan says that Whitman was "[m]ore interested in publicity than in praise" (153). In The Evolution of Walt Whitman (Iowa City: University of Iowa Press, 1999), Roger Asselineau says that Whitman's use of Emerson's letter is evidence of "the rowdy Walt in love with publicity" (84).

9 Jerome McGann, The Textual Condition (Princeton: Princeton University Press, 1991), 53.

10 Ralph Waldo Emerson, "Emerson to Whitman, 1855," Leaves of Grass, Comprehensive Reader's Edition, ed. Harold W. Blodgett and Sculley Bradley (New York: New York University Press, 1965), 729. Abbreviated LG.

11 Genette, 111-112. I am broadly defining Genette's discussion of the "pleaseinsert" as any endorsement of the text in the peritext.

12 John Rietz suggests this pun in “'Leaves-Droppings' (1856)," Walt Whitman: An Encyclopedia, ed. J. R. LeMaster and Donald D. Kummings (New York: Garland, 1998), 383. Grossman, 95, suggests a more scatological pun.

13 Walt Whitman, "Whitman to Emerson, 1856," LG, 730.

14 Kenneth Price, "Whitman on Emerson: New Light on the 1856 Open Letter," American Literature 56 (1984), 83-84.

15 Grossman, 84-85. It also bears noting that Whitman uses the word "poem" six times in the first paragraph of his reply letter to Emerson: "Here are thirty-two Poems. ... [the 1855 edition had] twelve poems. ... these thirty-two Poems. . . . I much enjoy making poems. ... the work of my life is making poems. . . A few years, the average annual call for my Poems is ten or twenty thousand copies" (LG, 730-31). 
16 In context, it reads, "Where are any mental expressions from you, beyond what you have copied or stolen? Where the born throngs of poets, literats, orators, you promised? Will you but tag after other nations?" (LG, 732).

17 "The Poet," The Critical Tradition: Classic Texts and Contemporary Trends, ed. David H. Richter (New York: St. Martin's, 1989), 368.

18 Anthony Szczesiul, "Walt Whitman and the Development of Leaves of Grass: Originally Exhibited March-April 1992, Thomas Cooper Library [University of South Carolina]," December 15, 1999: http://www.sc.edu/library/spcoll/amlit/whitman/ whitman.html (June 25, 1999). Floyd Stovall likewise says that "The Poet" "had a marked influence in shaping [Whitman's] image of himself as the new American poet that Emerson said he had looked for in vain" in The Foreground of Leaves of Grass (Charlottesville: University Press of Virginia, 1974), 296. Stovall offers numerous parallel passages comparing Emerson's “The Poet” and Whitman's statements about the role of the American bard.

19 Emerson, "The Poet," 368. See Grossman, 86, for an alternative reading of what Emerson means by "tyrannous eye."

20 Quoted in Horace Traubel, With Walt Whitman in Camden (1908, reprinted New York: Rowman and Littlefield, 1961), 2:69. This is how Whitman responded when Traubel tried to pin down the poet's opinion of Emerson.

21 "[William Howitt? or William J. Fox?]. London Weekly Dispatch, 9 March 1856, p.6," Walt Whitman: The Contemporary Reviews, ed. Kenneth M. Price (Cambridge: Cambridge University Press, 1996), 41. Also printed as "A favourable English reaction," Walt Whitman: The Critical Heritage, ed. Milton Hindus (London: Routledge, 1971), 78-79.

22 The international nature of the reviews is emphasized by the advertising copy appearing at the back of this edition, indicating that Leaves of Grass was available in thirteen international cities, including London, Toronto, Brussels, and Paris (see Joel Myerson, Walt Whitman: A Descriptive Bibliography [Pittsburgh: University of Pittsburgh Press, 1993], 26). In emphasizing the international reach of his poetry well before it had actually happened (i.e., there wouldn't be a British edition of Leaves of Grass until 1868), the advertising copy extends the narrative in "Leaves-Droppings" of Whitman as America's poet to make Whitman the ambassador for American poetry world-wide.

23 “[Walt Whitman]. 'Walt Whitman, a Brooklyn Boy'. Brooklyn Daily Times, 29 September 1855, p. 2," Price, 22. Also in "Whitman's Anonymous Self-Reviews," Hindus, 45-48.

24 Kenneth M. Price, "Introduction," in Price, xi, xiii. Susan Belasco Smith and Price write of the importance of the periodicals for authors to achieve publicity: "Later in the century, Dana Estes, a publisher who testified before a Senate committee considering international copyrights, commented on the economic importance of the periodicals to the profession of authorship as well as on the pervasiveness of the form in disseminating works of literature: 'It is impossible to make the books of most American authors pay unless they are first published and acquire recognition through the columns of magazines" ("Introduction: Periodical Literature in Social and Historical Context," Periodical Literature in Nineteenth-Century America, ed. Kenneth M. Price and Susan Belasco Smith [Charlottesville: University of Virginia Press, 1995], 6-7). 
25 “[Walt Whitman]. 'An English and American Poet'. American Phrenological fournal 22, no. 4 (October 1855), 90-1," Price, 26. Also in "Whitman's Anonymous SelfReviews," Hindus, 41-45.

26 "His style is everywhere graphic," in Hindus, 82, 84.

27 “[Charles Eliot Norton]. 'Whitman's Leaves of Grass'. Putnam's Monthly: A Magazine of Literature, Science, and Art 6 (September 1855), 321-3," Price, 14. Also in "Charles Eliot Norton's Review," Hindus, 24-27.

28 “Critic [London] 15 (1 April 1856), 170-1," Price, 43. Also in “An English Reaction," Hindus, 55-60.

29 “Examiner 2512 (22 March 1856), 180-1," Price, 42. Also in "a wild Tupper of the West," Hindus, 90-93.

30 Grossman touches on the fact that the negative reviews "may be very high praise indeed" based on the context Whitman has put them in and suggests "a previously unexpected possibility: that Whitman reads Emerson's letter not simply as an endorsement but as a negative review" like the others he reprints in "Leaves-Droppings" $(81,82)$.

31 “'Transatlantic Latter-Day Poetry'. Leader 7 (7 June 1856), 547-2," Walt Whitman: The Contemporary Reviews, Price, 50. Also in "Praise and Blame," Hindus, 94-96.

32 “An American Echo," Hindus, 61.

33 James L. Machor, "Introduction: Readers/Texts/Contexts," Readers in History: Nineteenth-Century American Literature and the Contexts of Response, ed. James L. Machor (Baltimore: Johns Hopkins University Press, 1993), xii.

34 David Hall, Cultures of Print: Essays in the History of the Book (Amherst: University of Massachusetts Press, 1996), 29. Discussing the availability of print outside of America in the nineteenth century, Hall writes, "Enumerating the elements of expansion as they unfolded in nineteenth-century England, the literary historian Richard Altick proclaimed the emergence of a 'democracy of print'. . . . [T] he social critic Raymond Williams, employed a similar framework ... where the 'growth of the reading public' in England, and especially the accelerating rate of growth after 1830, is linked to the 'democratic revolution' and a 'cultural revolution'” (175).

35 Ralph Waldo Emerson, "The Fugitive Slave Law," The Portable Emerson, ed. Carl Bode (New York: Penguin, 1981), 541-542.

36 See Richard Raleigh, “'Letter to Ralph Waldo Emerson' (1856),” Walt Whitman: An Encyclopedia, 390. Asselineau likewise says that the "reply to Emerson is a document of equal importance with the 1855 Preface" (85). Bradley and Blodgett say that the letter was "virtually a preface to his Leaves of Grass of 1856" (LG, 729).

37 Genette says "it is sometimes in one's interest to have certain things 'known' without having (supposedly) said them oneself" (10).

38 William Michael Rossetti, who edited the 1868 British edition, Poems by Walt Whitman [London, John Camden Hotten, Picadilly, 1868), wrote in his "Prefatory Notice," "the key-words of the whole book are two-'One's-self' and 'En Masse"' (5).

39 Quoted in Greenspan, 175, italics in original. 